\title{
Students' Ability in Using Direct and Indirect Speech of English Department Students at Universitas Muslim Indonesia
}

\author{
Rosmiaty \\ rosmiaty123@gmail.com \\ Politeknik Sandi Karsa \\ Ratnawati \\ ratnawati.ratnawati@umi.ac.id \\ Akademi Bahasa Asing UMI \\ Hasni Latukau \\ HasniL23@gmail.com \\ Akademi Bahasa Asing UMI
}

\begin{abstract}
In this study the writer wishes to know the students' ability by the fourth semester students of Foreign Language Academy UMI in using direct and indirect speech. The whole population of this study was 160 students at fourth semester of Foreign Language Academy. There were 24 students out of 160 students to represent the population as the sample. The sample is taken by using random sampling technique. The types of the test consist of simple past tense, simple present tense and future tense. Through the data, the researcher obtained that 1 student or $4 \%$ were included in the highest score or having excellent level. 1 student or $4 \%$ were included in good level. Then, 2 students or $9 \%$ were included in sufficient level, 20 students or $83 \%$ were included in the low score or having fail level. The result revealed that there were still many underprivileged students in learning this subject.
\end{abstract}

Keyword : Ability, Direct and Indirect Speech

\section{INTRODUCTION}

Language is not only used as a tool to communicate and interact with other people but through languages people can express their ideas, thoughts, and feelings about knowledge, culture and many things in the world. As people know, this world is big and wide. There are many countries with their own languages. In order to get communication and information well, English has grown rapidly and become a lingua franca. A lingua franca can be defined as a language widely adopted for communication between two speakers whose native language are 
different from each other and where are or both speakers are using it as a "a second language" (Harmer, 2001).

In Indonesia, English is the first foreign language that has been taught to elementary school until senior high school. In learning English, there are four skills that must be mastered, they are speaking, reading, listening and writing. Besides, master in language components are also needed, they are grammar, vocabulary and pronunciation in order to help people mastering in the four language skills above.

Bowers and Brumfit (1991) say that "grammar is a language". It means that if students learn a language, they will also learn the grammar of the language. Thus, learning grammar becomes an inseparable part of language and becomes an important aspect if the student wants to speak and write English well. This is because learning grammar involves not only the rules but also learning how to manipulate the devices that English speaker use to convey certain ideas. In addition grammar is important, especially when the learners communicate with others. Moreover, by mastering English grammar, the learners will know how to transfer and receive a message either in written or spoken language without misunderstanding. When English learners hear the word about grammar, they directly relate it to the study of the tenses. The reason is because tenses are the basic of grammatical study in English.

Someone who has mastered grammar properly will be different from a speaker who speaks English without good grammar comprehension. Someone who speaks or writes English properly or with good structure of sentences will be more acceptable and effective in his/her interaction in all aspects of his/her life because he/she does not only produce words, but also make listeners and readers reach his/her meaning easily either in oral or written English. There are many aspects discussed in English grammar, one of them is reported speech. Reported phrase is one of many grammatical categories which is important to be learned by students. It is needed to be learned because sometimes people will use it either in writing or daily conversation.

Reported speech will make a conversation more interactive. Students can give information that they have to other one by orienting to the information, not to the exact sentence either as statements, questions, or commands. It is different process of happiness when students want to report someone statements, questions or commands from direct into direct speech, the students have to make certain grammatical changes in order to speak properly in English, so Indonesian students may make some errors when learning reported speech. In English, when a speaker would like to report what he/she has listened from someone words either in statement, question or command form. The speaker should make some transformation such as tenses, pronoun and adverb of time because when the speaker is making reported speech; it will be a different time with the time when the source speaker said. Also he/she should change the pronoun of source speaker in order to make conversation acceptable and meaningful. From the explanation 
above, the writer is interested in finding out Students' Ability in Using Direct and Indirect Speech at Fourth Semester in Foreign Language Academy UMI.

\section{LITERATURE OF REVIEW}

In English grammar, reported speech is one of many grammatical categories which is important to be learnt by student. It is needed to be learnt because it is one of three ways for students to report or share their statement or thoughts to other people especially when they communicate between one each other. Wilson and Burk (1980) say that Reported speech is commonly used to report what other people have said or thought without reporting the exact word. With indirect reported speech, one wishes to report the content of the original source without necessarily repeating sentences exactly as the were originally untted. Azar (1992) said that reported speech refers to reproducing the idea of another person "es words. Not all of the exact words are used: verb forms and pronoun may change.

To report people word's, thoughts, and beliefs there are two main ways: direct and indirect speech. Reported speech is also used when people are interested not in the words that someone has chosen, but in the essential information they conveyed. Reported speech can be found in newspaper reports, fiction, talking or writing about conversation, reports, articles or speeches people have heard or read. By learning reported speech definitely student will able to quote somebody's words or thoughts, whether in direct or indirect speech and also the student will learn and understand the way to report speeches. From the definitions above, it can be concluded that reported speech is to quote sombody's idea or thoughts without exactly repeating the exact word produced by the speaker.

Direct speech is a means the content of statements, questions or other utterances by quoting them explicitly. Direct speech (also called quoted speech) states the exact words of a speaker. (Maurer, 2000) in direct speech we repeat the original speaker's exact words. In direct speech, quotation marks enclose the quotation. The reporting verb, such as said, told, or responded, is followed by comma if it introduces the quotation. Quotation marks come after a final period, question mark, or exclamation point. Parrot (2004) states that direct speech conveys exactly what someone has said often to dramatize, to create a sense of immediacy, and because the precise words used were in some way important (for example funny or strange). It means that direct speech as flavor to make sense in written text.

Indirect speech is a kind of structure that can make speakers words as a part of a reporter sentence by using conjunction, changing pronouns, tenses and other word where necessary then. Sergeant (2007) states that indirect speech is reporting what someone says without using their exact words. In 
transforming direct speech into indirect speech, students must be understood the grammar well.

When turning the direct into indirect speech, some changes are ussuly necessary. The tenses, pronoun and other words may different from the original sentence. Through grammar, students can transform direct speech into indirect speech correctly and they know the tenses. When transforms direct speech into indirect speech, the statement states in present form and changes into the past form. Indirect speech also called reported speech. Parrot (2004) says that indirect speech is used when it is interested not in the word that someone has chosen, but in the essential information they conveyed. It is often used far fewer words to report this than were originally spoken. Reported speech found in newspaper reports, fiction, talking, or writing about conversation, reports, articles or speeches that have been heard or read.

\section{METHOD}

The method of this research used descriptive quantitative analysis. The writer want to know the ability of students' in using direct and indirect speech especially at fourth semester in Foreign Language Academy UMI. To got the valid data, the writer gives a test about changed direct into indirect speech. The population of the research was the students at the fourth semester in Foreign Language Academy UMI. It consist of four classes, for totally they were 160 students in number. The writer not took the total of the population. As a sample, the writer only took $15 \%$ of population which is 24 students by using random sampling.

In this research, the writer gives test for collecting the data. the test that writer gives to the students was about essay test which is the writer gives the direct speech then the students changed to indirect speech. The writer used the descriptive quantitative analysis technique (percentage) to analyze the data. The data took by the documentation those are going to be analyze based on the answer to the test. To analyze the data, the steps are ad follows :

1. Checking the students answer sheet.

2. Correcting the students answer one by one.

3. Giving the students score. Scoring system of the test was given score one to each correct answers and zero to the wrong answer. Then, the total of correct answer was devided by the total test item and multiplied by 100, so that the highest score was 100 .

4. Determining the category or level of students' ability. The researcher classified the students' score one by one by using students' score.

5. Classifying the students' level ability. After the students' score was classified, the researcher put it into percentage of classification 
before making a chart for knowing the students' classification ability easily. The researcher used formula of percentage :

The formula of percentage (Sudijono, 2005)

$$
\mathrm{P}=\frac{\mathrm{F}}{\mathrm{N}} \times 100 \%
$$

$$
\begin{aligned}
& \mathrm{P}=\text { Percentage } \\
& \mathrm{F}=\text { Frequency of Correct or Incorrect answer } \\
& \mathrm{N}=\text { Number of sample which is observe }
\end{aligned}
$$

After getting average score, the writer compares the percentage with the criteria adopt from Arikunto's opinion in maisaroh (2013) present at table.

\section{Table 10. Criteria of Correct Result Percentage}

\begin{tabular}{|l|l|l|}
\hline \multicolumn{1}{|c|}{ No } & \multicolumn{1}{|c|}{ Range } & \multicolumn{1}{c|}{ Level } \\
\hline 1 & $80 \%-100 \%$ & Exellent \\
\hline 2 & $66 \%-79 \%$ & Good \\
\hline 3 & $56 \%-65 \%$ & Sufficient \\
\hline 4 & $40 \%-55 \%$ & Less good \\
\hline 5 & $30 \%-39 \%$ & Fail \\
\hline
\end{tabular}

Based on the criteria of correct result percentage above, it can be divede in to the high , middle, and low score :

$$
\begin{array}{ll}
\text { The high score } & : 80 \%-100 \% \\
\text { The middle score } & : 56 \%-79 \%
\end{array}
$$

The low score $\quad:<30 \%-55 \%$

\section{RESULT AND DISCUSSIONS}

As stated in the preceding chapter, this research is focused on students' ability in using direct and indirect speech by forth semester students of foreign language academy. To get the data, the researcher gives essay test that the test consist of 15 items which is the students have to changes the tenses in the test.

The researcher conducted the research on $7^{\text {th }}$ and $12^{\text {th }}$ may 2019 at. At the time the researcher delivered her aim to students, then she gave the test of students' ability in using direct and indirect speech to them. After the researcher collected the data and then analyzed the result of the students' test.

In computing the data, the researcher corrected the students' answer sheet. The researcher gave one score for correct answer and zero score for wrong 
answer. After the data were collected, the researcher analyzed them. The steps were follows:

1. Determining the level of students' ability in using direct and direct speech. Scoring system of the test was given score one to each correct answer and zero to wrong answer. Then the total of correct answer was divided by the total test item and multiplied by 100, so that the highest score was 100 . Based on the result of counting the test, the students' score can be seen on the table below :

Table 11. The result of students' ability in using direct and indirect speech

\begin{tabular}{|l|c|c|c|c|c|}
\hline No & Code of students & Right Answer & Item & Level of ability & Quality \\
\hline 1 & FF & 2 & 15 & 13 & Fail \\
\hline 2 & AS & 2 & 15 & 13 & Fail \\
\hline 3 & RA & 0 & 15 & 0 & Fail \\
\hline 4 & AG & 14 & 15 & 93 & Excellent \\
\hline 5 & WM & 2 & 15 & 13 & Fail \\
\hline 6 & MJ & 1 & 15 & 7 & Fail \\
\hline 7 & JT & 0 & 15 & 0 & Fail \\
\hline 8 & HY & 1 & 15 & 7 & Fail \\
\hline 9 & MF & 3 & 15 & 20 & Fail \\
\hline 10 & MN & 0 & 15 & 0 & Fail \\
\hline 11 & FN & 1 & 15 & 7 & Fail \\
\hline 12 & RS & 3 & 15 & 20 & Fail \\
\hline 13 & HN & 0 & 15 & 0 & Fail \\
\hline 14 & TP & 0 & 15 & 0 & Fail \\
\hline 15 & N & 3 & 15 & 20 & Fail \\
\hline 16 & L & 2 & 15 & 13 & Fail \\
\hline 17 & M & 0 & 15 & 0 & Fail \\
\hline 18 & AMA & 1 & 15 & 7 & Fail \\
\hline 19 & YDF & 10 & 15 & 67 & Good \\
\hline 20 & MAJ & 3 & 15 & 20 & Fail \\
\hline 21 & FR & 3 & 15 & 20 & Fail \\
\hline 22 & JFT & 9 & 15 & 60 & Sufficient \\
\hline 23 & NIF & 9 & 15 & 60 & Sufficient \\
\hline 24 & MF & 1 & 15 & 7 & Fail \\
\hline \multicolumn{7}{|r|}{ The total score } & & 467 & \\
\hline & \multicolumn{2}{|c}{ Mean score } & & 19,5 & \\
\hline
\end{tabular}

From the table, it can be seen that there were 1 student got 93, 1 student got 67, 2 student got 60, 5 students got 20, 4 students got 13, 5 students got 7 and 6 students got 0 . These explanations can be seen in the 


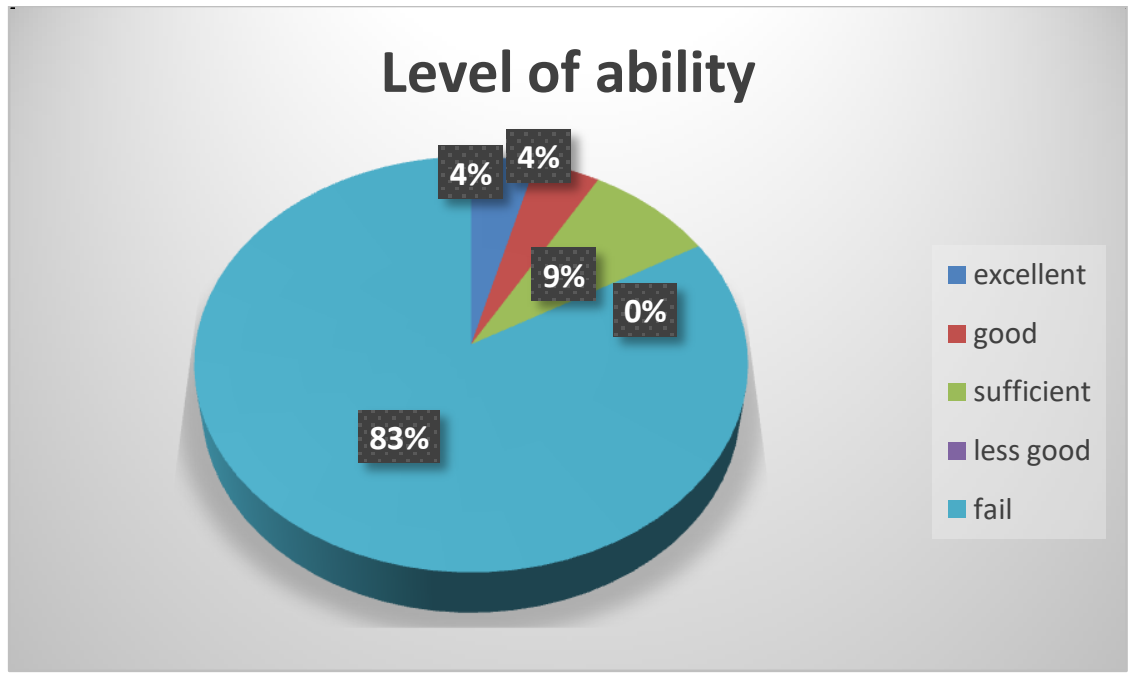

2. Finding out the percentage of classification

After the students' score was classified, the researcher found the percentage of classification. The formula of percentage was :

Notes :

$$
p=\frac{f}{N} x 100 \%
$$

$\mathrm{P} \quad$ : percentage number

f : frequency

$\mathrm{N}$ : number of sample which is observe

The frequency of each students classification wa calculated as follows:

$\begin{array}{ll}\text { Excellent } & : 1 \\ \text { Good } & : 1 \\ \text { Sufficient } & : 2 \\ \text { Less good } & : 0 \\ \text { Fail } & : 20\end{array}$

The percentage of students' ability in using direct and indirect speech :

a. The percentage of students' ability in using direct and indirect speech that having excellent level. There were 1 student in this level. The percentage was as follows :

$$
p=\frac{1}{24} \times 100 \%=4 \%
$$

b. The percentage of students' ability in using direct and indirect speech that having good level. There were 1 student in this level. The percentage was as follows :

$$
p=\frac{1}{24} \times 100 \%=4 \%
$$

c. The percentage of students' ability in using direct and indirect speech that having sufficient level. There were 0 student in this level. The percentage was as follows : 


$$
p=\frac{2}{24} \times 100 \%=9 \%
$$

d. The percentage of students' ability in using direct and indirect speech that having less good level. There were 0 student in this level. The percentage was as follows :

$$
p=\frac{0}{24} \times 100 \%=0 \%
$$

e. The percentage of students' ability in using direct and indirect speech that having fail level. There were 22 students in this level. The percentage was as follows :

$$
p=\frac{20}{24} \times 100 \%=83 \%
$$

The calculation can be seen in the following table :

Table 12. The percentage result of students' classification

\begin{tabular}{|c|c|c|}
\hline Level of ability & Frequency (f) & Percentage (p) \\
\hline Excellent & 1 & $4 \%$ \\
\hline Good & 1 & $4 \%$ \\
\hline Sufficient & 2 & $9 \%$ \\
\hline Less good & 0 & $0 \%$ \\
\hline Fail & 20 & $83 \%$ \\
\hline Total & $\mathbf{2 4}$ & $\mathbf{1 0 0 \%}$ \\
\hline
\end{tabular}

The distribution of the percentage of the students' classification level of ability can be seen in the following graph :

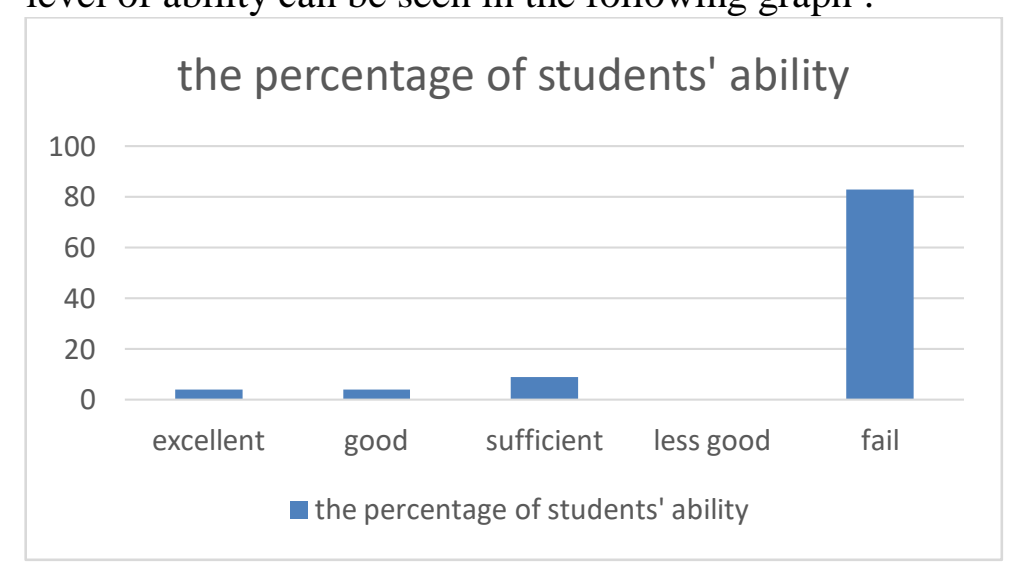

Based on the result, it can be concluded that the students' ability in using direct and indirect speech at fourth semester in foreign language academy belongs to fail.

\section{Discussion}

This section discussed about the result of the test in using direct and indirect speech. The researcher used essay tests an instrument. The test consisted of 15 items which was devided into three tenses. They were simple past, simple present and simple future. 
Through the data, the researcher obtained that 1 student or $4 \%$ were included in the highest score or having excellent level. 1 student or $4 \%$ were included in good level. Then, 2 students or $9 \%$ were included in sufficient level, 20 students or $83 \%$ were included in the low score or having fail level. It meant that the students' ability belong to fail by result percentage which was $83 \%$ (can see at the table 12 on page 29). So, the result revealed that there were still many underprivileged students in learning this subject. The reason that the students were at the level:

1. Excellent level

Only 1 or $4 \%$ student got this level, the reason is he really understand about this subject also he knows the formula about changes the tenses, it meant that he really understand about grammar. When he answered the questions that the researcher gave, he never ask about the question. So, the researcher took the result that the student really good in this subject.

2. Good level

Same with excellent level which is only 1 or $4 \%$ student got this level, it meant she good enough in this subject. She knows how to changes the tenses but sometimes she forgot the formula so she need times to thinking about the answer.

3. Sufficient level

In this level, the researcher got 2 or $9 \%$ students. The students who are in this level confused about the formula.

4. Fail level

The students were in this level is 20 or $83 \%$ students, it meant almost all of the respondent who participate in this research got fail level. The reason was the students did not really understand about the subject, they didn't know about the formula also they didn't know how to changes the tenses.

\section{CONCLUSIONS, IMPLICATION, AND SUGGESTIONS}

Based in data analysis, it can be drawn conclusion that students' ability level in using direct and indirect speech is very low. It can be know by the percentage of the fail level were $83 \%$ or 20 students from 24 students, it meant that most of the students at fourth semester in foreign language academy not really understand about direct and indirect speech.

Considering the result of the research, the researcher would like to deliver some suggestion as follows:

1. For the teacher

The teacher should be creative in teaching direct and indirect speech. For example use games that make all of the students can participate in learning activity. The teacher should give motivation and stimulate to the students to increase the students' ability in using direct and indirect speech. 
2. For the students

The students should have high motivation, pretension, and curiosity to learn something in learning English, especially about direct and indirect speech. The students should be active in the class, such as in asking and answering, discussion, and so on especially about direct and indirect speech material, because direct and indirect speech really important in our daily conversation.

3. For the other researcher

The research hopes that this research can be used as a reference for a research about direct and indirect speech with different objective, sample, and methodology.

4. For the readers

After reading this research, the readers are hoped to get information, knowledge, and advantages especially about direct and indirect speech.

\section{REFERENCES}

Alexander, L.G. 1998. Longman English Grammar Practice: For Intermediate Students. Longman. New York.

Arham, M., Akrab, A.H. (2018), Delving into Delving into Content Lecturers' Teaching Capability in Content Language Integrated Learning (CLIL) at an Indonesian University, Asian ESP Journal, Vol. 14 No. 7.2 (2018).

Anas sudijono, Pengantar Statistik Pendidikan, (Jakarta: PT. RajaGrafindo Persada, 2005). Fifteenth, p.43

Betty Schrampfer Azar, Fundamental of English Grammar, (London; Prentice Hall, 1992)

Harmer, J. 2001. The Parctice of English Language Teaching. Cambridge : Longman

Harman, S.E dan Homer, C. House. 1950. Descriptive English Grammar, Second Edition. New York: Prentice Hall Inc.

http://www.google.com/url?sa=t\&source=web\&rct=j\&url=https://inglescarmelitaslb.files. wordpress.com/2011/05/reportedspeech.pdf\&ved=2ahUKEwiK3P2fl73hAh Wp7XMBHYCGAkoQFjABegQIBRAB\&usg=AOvVaw1E4PFoO3ES7Eci YIjQgTPn (accessed on Sunday at 2:19 pm)

https://firstenglish.org/english_learning/reported_speech/50_reported_speech_simple_pas t_past_perfect.htm (accessed on Wednesday at 10:27 pm) 
https://www.tolearnenglish.com/exercises/exercise-english-2/exercise-english 114272.php (accessed on Wednesday at 10:43 pm)

https://firstenglish.org/english_learning/reported_speech/85_reported_speech_englisch_w ill_future_questions.htm (accessed on Wednesday at 11:55 pm)

http://www.edufind.com/english/grammar/reported_speech_questions_forms.php http://www.englishforums.com/content/lessons/indirect-reported-and-direct-speech.htm http://uogenglish.wordpress.com/english-lecture-notes/eng-102/306-2/

Jennifer Peat, Scientific Writing; Easy When Your Know How, (London: BMJ Books, 2002)

Jeremy Harmer, The Practice of English Language Teacheng, (Ney York: Longman Group, 1991)

Maurer, Jay, 2000. Focus on Grammar: An Advance Course for Reference and Practice. New York: Pearson Education, 2nd ed.

Parrot, Martin. 2004. Grammar for English Language Teachers. Cambridge: Cambridge University Press.

Roger Bowers and Christoper Brumfit, Applied Linguistics and English Linguistics and English Language Teaching, (London: Macmillan Publisher Limited, 1991).

Rodney Huddleston and Geoffrey K.pullum, A Student Introduction to English Grammar, (Ney York: Cambridge University 2010),

Seargent. 2007. Dictionary. Cambridge.org. Grammar. Page 139

Siti Maisaroh (2013), Analysis of The Students' Ability in Using Simple Past Tense, (Department of English Education)

Thomas W. Stewart and Jr. Nathan Vailette, (2001) Language Files; Materials for an Introduction to Language and Linguistics, (Department of Linguistics The Ohio State University) 